\title{
ステンレス鋼および耐熱鋼の基礎的研究
}

\author{
松 永 陽 之 助**
}

1. ニッケル・クロム, コバルト・クロム, 鉄・クロ ム, 鉄・ニッケル・クロムおよびニッケル・コバルト・ クロム平衡状態図について

筆者は大正 15 年より昭和 11 年にいたる 11 年間に 耐熱耐酸鋼または合金の基礎となる $\mathrm{Ni}-\mathrm{Cr}, \mathrm{Co}-\mathrm{Cr}, \mathrm{Fe}-$ $\mathrm{Cr}$ 二元拈よび $\mathrm{Fe}-\mathrm{Ni}-\mathrm{Cr}, \mathrm{Ni}-\mathrm{Co}-\mathrm{Cr}$ 三元の平衡状態図 についての研究を行なった。

これによって筆者が本邦に扣いて操業を開始した電熱 線および 18-8 ステンレス鋼の製造に対し，学術的基礎 を確立したばかりでなく，さらに有力なる酎熱耐酸鋼ま たは合金の要望に対する金相学的基礎を準備した。

筆者がこれらの研究を発表してから 40 年の歳月が流 れている。この間, 装置方法の新開発, 原料とくにク口 ム純度の向上が著しい。したがって細目の問題について は研究成果は日を追って精緻となっているが，ここに大 きな問題を二つ揭げて筆者の研究と現状とを対比して考 えたい。一つは $\mathrm{Fe}-\mathrm{Cr}$ ，したがって $\mathrm{Fe}-\mathrm{Ni}-\mathrm{Cr}$ 系に起こ ってくる問題である。いま一つは研究対象としたすべて の状態図に関係のある問題である。

(a) $\sigma$ 相

筆者が $\mathrm{Fe}-\mathrm{Ni}-\mathrm{Cr}$ 三元系状態図（図 1）を研究発表す

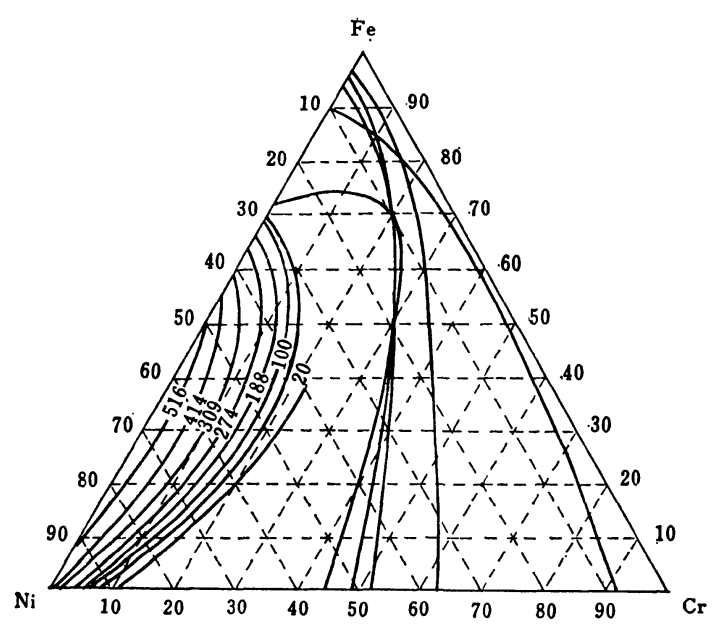

図 $1 \mathrm{Fe}-\mathrm{Ni}-\mathrm{Cr}$ 三元平衡状態図

* 昭和 44 年 1 月 23 日, 学振腐蝕防止第 97 委員会授賞 式における記念講演

** 日本治金工業株式会社（東京都中央区宝町 1-7 味の素 ビル)
る数年前, Bain および Wever などによって $\mathrm{Fe}-\mathrm{Cr}$ ま たは $\mathrm{Fe}-\mathrm{Ni}-\mathrm{Cr}$ 系に, やや広い範囲に金属間化合物 $\sigma$ のあることが提案されていた。筆者の三元系研究の顕微 鏡写真に括いても，5\% Ni-57\% Cr-38\% Fe, 60\% Cr40\% Fe などに明らかに異相を認めている。

$\sigma$ 相は長時間の焼鈍によって，その析出が確認される ものであるらえに, 当時ようやくその存在が提案されて いた $\mathrm{Fe}-\mathrm{Ni}$ 系の規則格子問題などと連関してあ劣て状 態図に取り入れることを避けた。少なくとも実用合金鋼 を製造する場合に，普通の作業標準をもってするならば， この相の出現が生産を妨げることは少ないものと考えた。

現にステンレス原料として使用している低炭素フェロ クロム $(60 \% \mathrm{Cr})$ は破砕にははなはだ困難であるが， これを適当な温度で焼鈍して破砕を容易ならしめた例は 見聞したことがない。

Metals Handbook 1948 年版 1261 頁にはすでに $\sigma$ 相 を導入した $\mathrm{Fe}-\mathrm{Ni}-\mathrm{Cr}$ 系の $650^{\circ} \mathrm{C}$ に拈ける状態図と， 急冷した $0.1 \% \mathrm{C}$ の常温状態図が掲げられている。の相 の存在範囲が時間とは無関係に常にかような分布をして いるよらに考えられているが，ステンレス鋼の製造ある いは溶接など加工業者が今日座右に置いて作業の指針と しているものはこれら状態図でなくSchaeffler の状態 図である。それは焼入れを考虑に入れた場合の Metals Handbook の急冷状態図とともに筆者の状態図と一致し ている。すなわち筆者の $\mathrm{Fe}-\mathrm{Ni}-\mathrm{Cr}$ 三元状態図は今日と いえぞも大綱に拈いて誤りないことを裏書きしている。

\section{(b) クロムの変態}

筆者は $\mathrm{Ni}-\mathrm{Cr}$ 二元系のX線研究をした折, $\mathrm{Cr}$ の変態 点について焼入れその他の方法をもって調べたが，確認 するにはいたらなかった。最近 Cr の変態点の存在が確 認され $\mathrm{Ni}-\mathrm{Cr}$ 二元系については，これを導入した状態 図の発表もある。 $\mathrm{Cr}$ の変態を導入して考えると, Ni$\mathrm{Cr}, \mathrm{Co}-\mathrm{Cr}, \mathrm{Fe}-\mathrm{Cr}, \mathrm{Fe}-\mathrm{Ni}-\mathrm{Cr}, \mathrm{Ni}-\mathrm{Co}-\mathrm{Cr}$ の $\mathrm{Cr}$ 側に ついては従来の研究全部が書き直されねばならぬ時期が 来ている。もっとも, これらの系に属する実用合金につ いては $\mathrm{Cr}$ の変態点の存在が及ぼす影響について, さし あたり別に考慮の要はない。要するに筆者の研究は工業 的見地からは大綱に拈いて正鵠妥当である。

電熱線, 18-8 ステンレス鋼その他の耐熱耐酸鋼の製造 に当って, 筆者が本研究の成果を利用した所は少なしと 
しない。以下その二，三の例を詳記したい。

$\mathrm{Ni}-\mathrm{Cr}$ 二元状態図（図 2) の決定によって, $\mathrm{Ni}$ 中の Cr の溶解度は常温に拈いて 44\%，したがって実用合金 として最高級品とされていた電熱線 1 号 $(80 \% \mathrm{Ni}-20 \%$ Cr) の Cr 量は溶解限度 $(44 \%)$ の $50 \%$ にも達しない ことが明らかとなった。したがって，この合金の製造に 当って，その $\mathrm{Cr}$ 量を若干低くすることによっては，そ の加工性の改善は期し難いことが明らかとなったので, このためには何か他の方法が必要であることを知った。

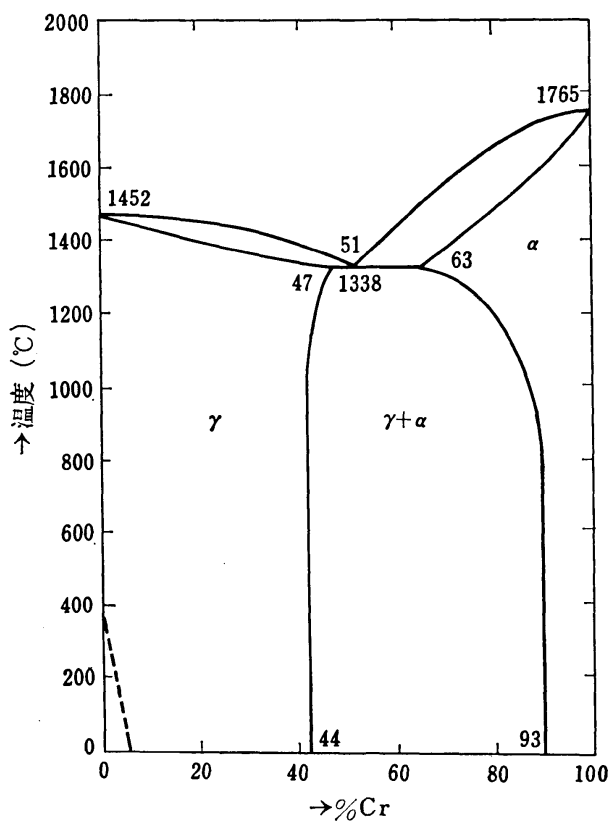

図 $2 \mathrm{Ni}-\mathrm{Cr}$ 二元平衡状態図

水素, 酸素, 硫黄が $\mathrm{Ni}$ の加工性に悪影響のあること を経験および文献によって知った筆者は，適当な方法で まず水素を除去して後, 差支えない限り Mn 量を高く し $(2 \%)$ さらに $\mathrm{Mg}$ または $\mathrm{Ce}, \mathrm{La}$ 等の希土金属をも って, 脱酸, 脱硫を完全にすることによって, 電熱線の 加工性を改善することに成功した。

耐熱鋼 NAS-20 (20\% Ni-25\% Cr) の高温加工性を改 良するために $\mathrm{Mn}$ を高くし, Ce, La 等の希土金属を用 いることは，今日ステンレス業者の工業常識である。

次に $\mathrm{Fe}-\mathrm{Cr}$ 二元系（図 3）の研究による成果を揭げ たい。当時広く用いられていた Oberhoffer の研究によ ると, この系の $\mathrm{Cr}$ 含有量 $20 \%$ 付近のものは, 融点が $1,400^{\circ} \mathrm{C}$ 前後であると発表されていた。これは電熱線 1 号 $(80 \% \mathrm{Ni}-20 \% \mathrm{Cr})$ の融点, $1,400 \sim 1,410^{\circ} \mathrm{C}$ と変り がない。したがって，この二元系合金を電気抵抗発熱線 として利用する場合, 機械的あるいは電気的劣性を補う 他の特性は考えられなかった。

筆者は本研究によって, この二元系の最低融点は, 20

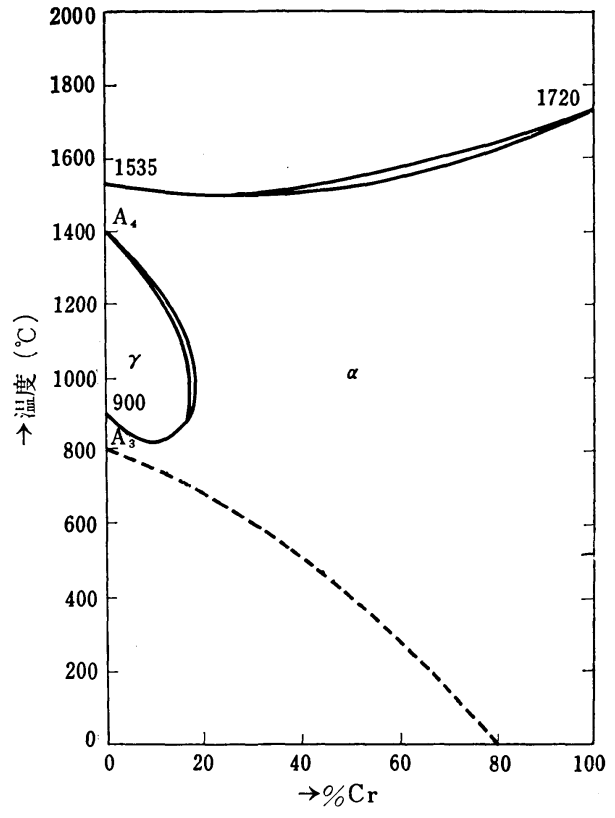

図 $3 \quad r \mathrm{re}-\mathrm{Cr}$ 二元平衡状態図

〜25\% Cr の所にあって，その值は $1,510^{\circ} \mathrm{C}$ 付近である ことを知った。したがって，これを基合金とする電気抵 抗発熱線は従来の 1 号電熱線に比べて, 的 $100^{\circ} \mathrm{C}$ 高い融 点をもつことが予想されたので，筆者はこの系に $\mathrm{A} 1$ を 添加した代用電熱線の製造の研究に着手し, 昭和 6 年, 日本鉄鋼協会秋期大会講演会に括いて，その基礎的部分 を発表し，後その伸線加工に対する特許を得ている。戦 中戦後 $\mathrm{Ni}$ の使用が制限された時に, この研究によって 電熱線の様相が一変し, 従来の $\mathrm{Ni}-\mathrm{Cr}$ 系から $\mathrm{Fe}-\mathrm{Cr}-$ A1 系に移行する因を作った。本研究に対しては昭和 4 年商工省工業奖励金の補助を受けている。また戦争末期 には海軍省艦政本部の要請に応えて, 高温使用目的で改 めてこの種の電熱線の製造研究をした。

また $\mathrm{Fe}-\mathrm{Ni}-\mathrm{Cr}$ 三元系の研究によって，18-8 ステンレ ス鋼が Ni の固溶体であることを確認した。この固溶体 はきわめて不安定な固溶体であって, 加工, 加熱, 低温 処理または，これらの組合せによって，直接 $\mathrm{Fe}, \mathrm{Cr}$ を 析出するか，または炭素等さらに原子量の小さい元素の 析出を助長する。しかしこの鋼は $\mathrm{Fe}-\mathrm{Ni}$ 二元系の $\mathrm{Ni}$ 中の $\mathrm{Fe}$ の固溶度が $\mathrm{A}_{3}$ 変態以下では温度の下降にした がって次第に減少し, 標準状態では $28 \% \mathrm{Fe}$ となるが,こ れに加工，加熱，低温処理または，これらを組合せた場 合に $\mathrm{Ni}$ の固溶体から過㮃の $\mathrm{Fe}$ の析出を見ることは周 知の事実である。18-8 ステンレス鋼 $(8 \% \mathrm{Ni}-18 \% \mathrm{Cr})$ は，まったくこれと等しい金相学的様相を含み，適当な 温度 $\left(1,100 \sim 1,200^{\circ} \mathrm{C}\right)$ では, その $\mathrm{Ni}$ 中の $\mathrm{Fe}$ の溶解 度が最高となるが，常温あるいは，さらに低い温度では 
溶解度が減じ，Fe を析出するようになる。ただしその 含有する $\mathrm{Cr}(18 \%)$ とよって, 常温执よび低温に拈け る鉄の析出が防止されているのである。適当量の $\mathrm{C}, \mathrm{Mn}$ および $18 \%$ 以下の $\mathrm{Cr}$ は $\mathrm{Ni}$ 中の $\mathrm{Fe}$ の溶解度を助長 し, $\mathrm{Al}, \mathrm{Si}, \mathrm{Ti}, \mathrm{Cb}, \mathrm{Mo}$ 拈よび $18 \%$ 以上の $\mathrm{Cr}$ は $\mathrm{Ni}$ 中の $\mathrm{Fe}$ の溶解度を减少させる。したがって 18-8 ステ ンレス鋼を製造するに当っては，溶媒である $\mathrm{Ni}$ の量は これを選ぶに十分なる注意を払わなければならない。

不純物を厳密に調整することは困難であるので, 溶媒 である Ni の量は, これを選ぶのに慎重を期さなければ ならない。たとえば，極低炭素 $(0.030 \% \mathrm{C})$ のステンレ ス鋼は, $\mathrm{Ni}$ 中の $\mathrm{Fe}$ の溶解度を助長するのに最有力で ある炭素が標準型である $0.08 \% \mathrm{C}$ のるのに比べて著し く低いので，その Ni 量を少なくとも9 9.5\% に保た なければ, その組織をいわゆるオーステナイト状に保ち, 無磁性とすることは期しにくい。

状態図によって 18-8 ステンレス鋼が過飽和の Ni の 固溶体であることを確認した筆者は，これが工業化に当 って, その Ni 量を9 9.5\% と選んだ。その後, 陸軍 火工廠の好意により同廠が所持するドイッ・クルップ社 製ステンレス・スクラップ約 $7 \mathrm{t}$ を入手し，板厚ごと 飞鑑別して分析および腐食試験を行なったことがあるが， その $\mathrm{Ni}$ 含有量は 9 9.5\% で著者の考光を裏書きした。

今日では Ni の高い 18-8 ステンレス鋼はステンレス 鋼製造業者の常識で JIS に扔いても AISI に括いてもそ の $\mathrm{Ni}$ 含有量は $8 \%$ より高いものが製造されるように規 定されている。中性子の吸収を考虑に入れて製造する原 子炉用ステンレス鋼で極低炭素のものを造る場合，また は製造化学機械用として造る極低炭素 Mo ステンレス 鋼、またはMo ステンレス鋼に $\mathrm{Cb}$ を加えたものを造る 場合に㧊いては, とくに Ni の量を高くする必要がある。

大量に用いられる原子炉用細管に最近 18-8 ステンレ ス鋼に代って Inconel (75〜80\% Ni-15〜20\% Cr-5\%以 下の $\mathrm{Fe}$ ）が使用されるようになったことを聞く。これ は超安定相である Inconel が炭素, 残留応力等によって 粒界腐食あるいは応力腐食割れなどに対し, 安全性が高 いためであることは, 両者が Ni の固溶体で, その含有 $\mathrm{Ni}$ 量に格段の開きがあることを考虑すれば, 容易にこ れを肯定できる。

昭和 5 年 $\mathrm{Fe}-\mathrm{Ni}-\mathrm{Cr}$ 三元系の平衡状態図を決定して後, 引き続いてその硬度扣よびこの系の機械試験を行なった (図 4, 5 抢よび図 6)。機械試験結果と三元平衡状態図 の関係を調べてみるとニッケルの固溶体 $r$ と鉄の固溶体 $\alpha$ 共存する範囲内で, $\gamma$ に近い部分に強さが大きくて, 伸びの小さくないものがあり，rの範囲には強さが標準 18-8 ステンレスに比べて約 20\% 低いものがあることを 確認した。

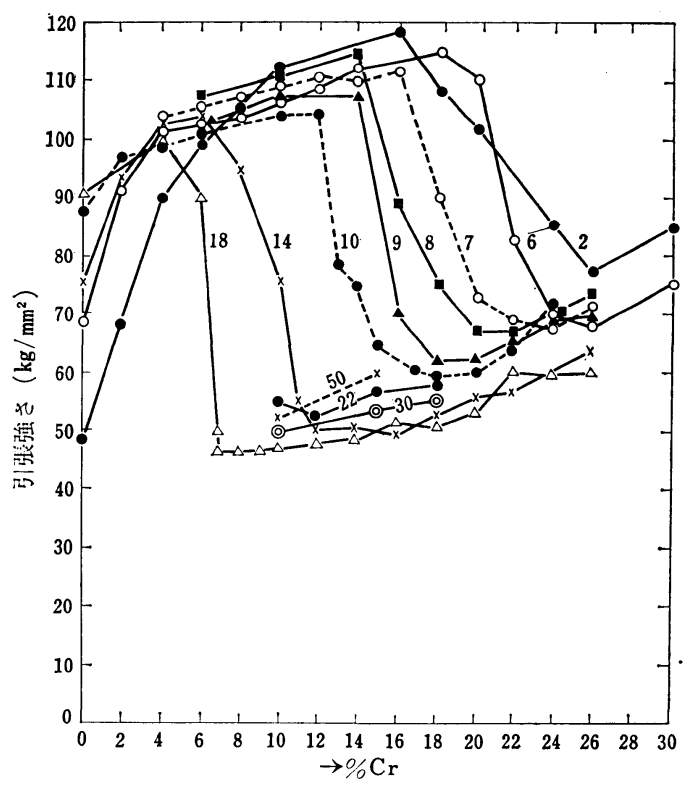

図 $4 \mathrm{Fe}-\mathrm{Ni}-\mathrm{Cr}$ 合金の引張強さと $\mathrm{Cr}$ 含有量の関係 （折線上の数字は $\mathrm{Ni} \%$ を示す）

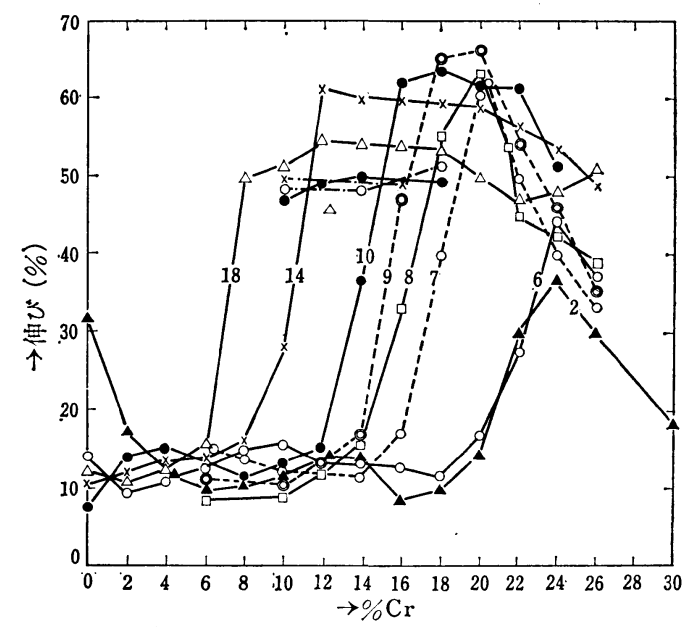

図 $5 \mathrm{Fe}-\mathrm{Ni}-\mathrm{Cr}$ 合金の伸びと $\mathrm{Cr}$ 含有量の関係 （折線上の数字は $\mathrm{Ni} \%$ を示す）

前者は強力ステンレス鋼の基合金として，後者は軟質 ステンレス鋼の基合金として新しい用途が予約される。 また図 7 に示すようにニッケル中の鉄の固溶度を助長す るものとして知られている Mn によって, ニッケルの 相当量を置換した $\mathrm{Fe}-\mathrm{Ni}-\mathrm{Mn}-\mathrm{Cr}$ 鋼の研究をした。その 結果, $\gamma, \alpha$ 共存の範囲には強さが標準型 18-8 ステンレ ス鋼に比べて $50 \%$ 高く, しかも伸びには何の差異もな いものを発見している。

また筆者は，標準 18-8 オーステナイト鋼を基合金と する $\mathrm{Al}, \mathrm{Ti}$ 打よび Bを含む時効性 18-8 ステンレス鋼 


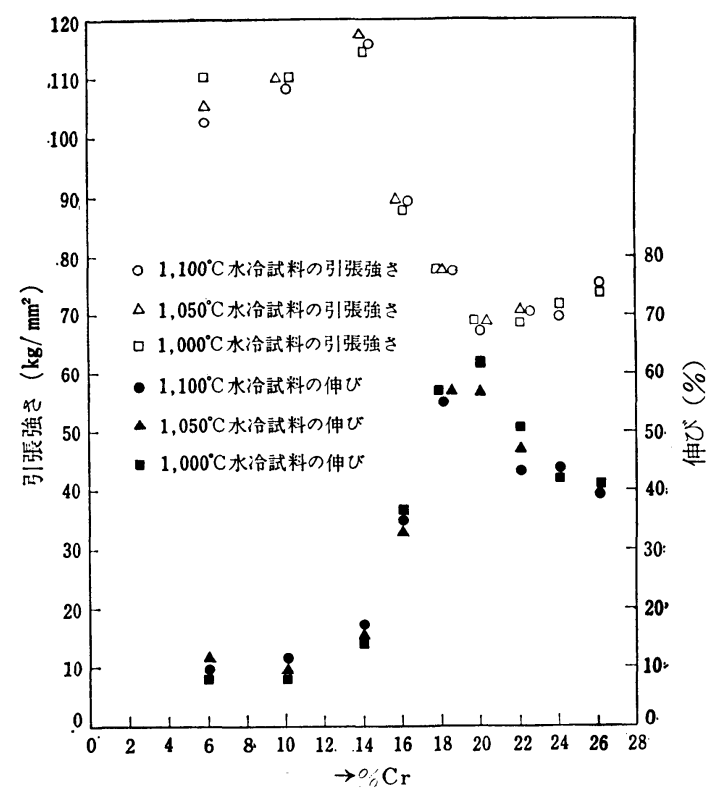

图 $68 \% \mathrm{Ni}-0 \sim 26 \% \mathrm{Cr}$ の $\mathrm{Fe}-\mathrm{Ni}-\mathrm{Cr}$ 合金の引張試験結果

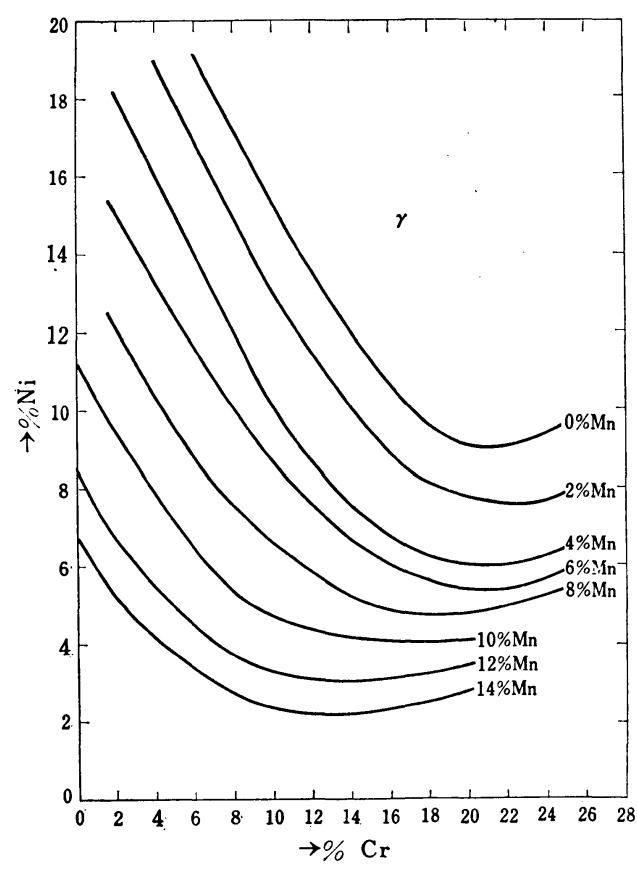

図 $7 \mathrm{Fe}-\mathrm{Ni}-\mathrm{Cr}$ 合金に $\mathrm{Mn}$ を添加した場合の単相 オーステナイト生成領域

を発見している。上述の $\mathrm{Fe}-\mathrm{Ni}-\mathrm{Mn}-\mathrm{Cr}$ 系の強力ステン レス鋼は，超強力時効性ステンレス鋼の基合金鋼として 研究をしたものであるが，戦争によって中断している。 もっとも，この鋼を基合金鋼とした時効性ステンレス鋼 には今日公知の 17-7 PH または 16-4 PH 析出硬化型ス テンレス鋼に比べて,さらに強力なるものの発見が予想
される。これら研究はすべて状態図から示唆を受けたも のである。

$\mathrm{Ni}-\mathrm{Co}-\mathrm{Cr}$ あるいは，これに若干の $\mathrm{Fe}$ を含むものに ついては，筆者は昭和 3 年 1 月 26 日付をもって特許第 75280 号を得ている。戦中戦後, ガスタービン, ターボ ジェット機関はもちろん, ロケットの開発等に当って $\mathrm{Ni}-\mathrm{Co}-\mathrm{Cr}$ 三元系が基合金となって，今日の合金として 脚光を浴びていることについては，いまさら，貲言を要 しない。大戦中本邦を捲土した米機 B 29 の過給機用ガ スタービン翼材は $\mathrm{Co}-\mathrm{Cr}$ を基合金とした Co-Cr-Mo 系 合金であった（図 8 特よび図 9)。

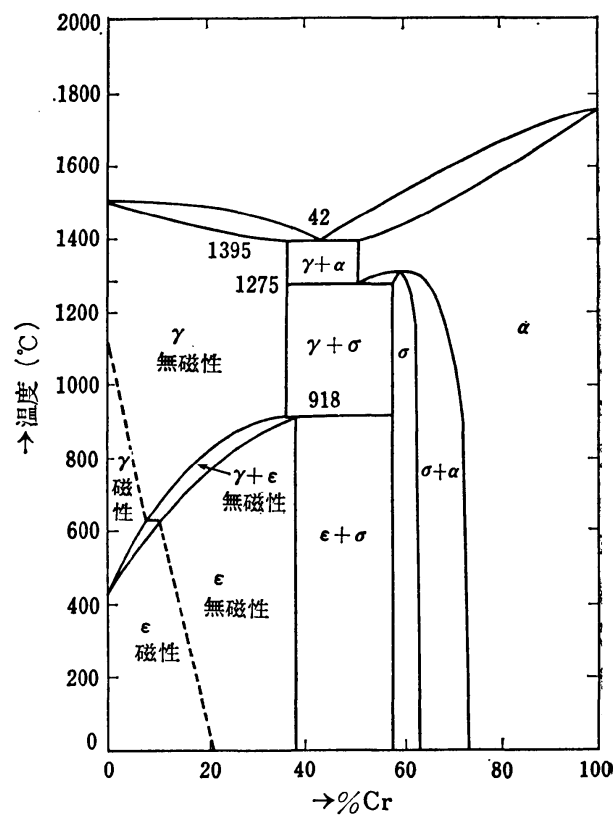

図 $8 \mathrm{Co}-\mathrm{Cr}$ 二元平衡状態図

\section{18-8 ステンレス鋼の耐食性試験}

昭和初期, 18-8 ステンレス鋼の炭素量は海外でも 0.08 \%以下のものは，ごく希れであった。したがって，粒界 腐食を考虑した場合, 溶接または機械加工後必ず所定の 熱処理を施こさねばならなかった。そこで腐食試験は, $1,100^{\circ} \mathrm{C}$ から水焼入れをした状態に㧧いてこれを行なっ た。ステンレス鋼の最も大きい消費者であった陸軍火薬 廠に扣いては熱処理を施した試片について $40 \%$ 硝酸液 中で煮沸して，その減量に従って採否を定めた。

硝酸による不働態化処理は濃度 $40 \%$ 前後が最適であ るから,この試験は最良の状洗において酸化性酸中にお けるステンレス鋼の腐食を調べる方法である。筆者は, Krupp, Schöller-Bleckmann, Avesta 等の会社から, $1.2 \mathrm{~mm}$ 厚の定尺のステンレス鋼板を輸入し, 自家工場 で造った板とともにこの試験方法によって耐食性を調べ てみた。炭素は 0.1〜0.54\%のもので, ニッケルは8〜 


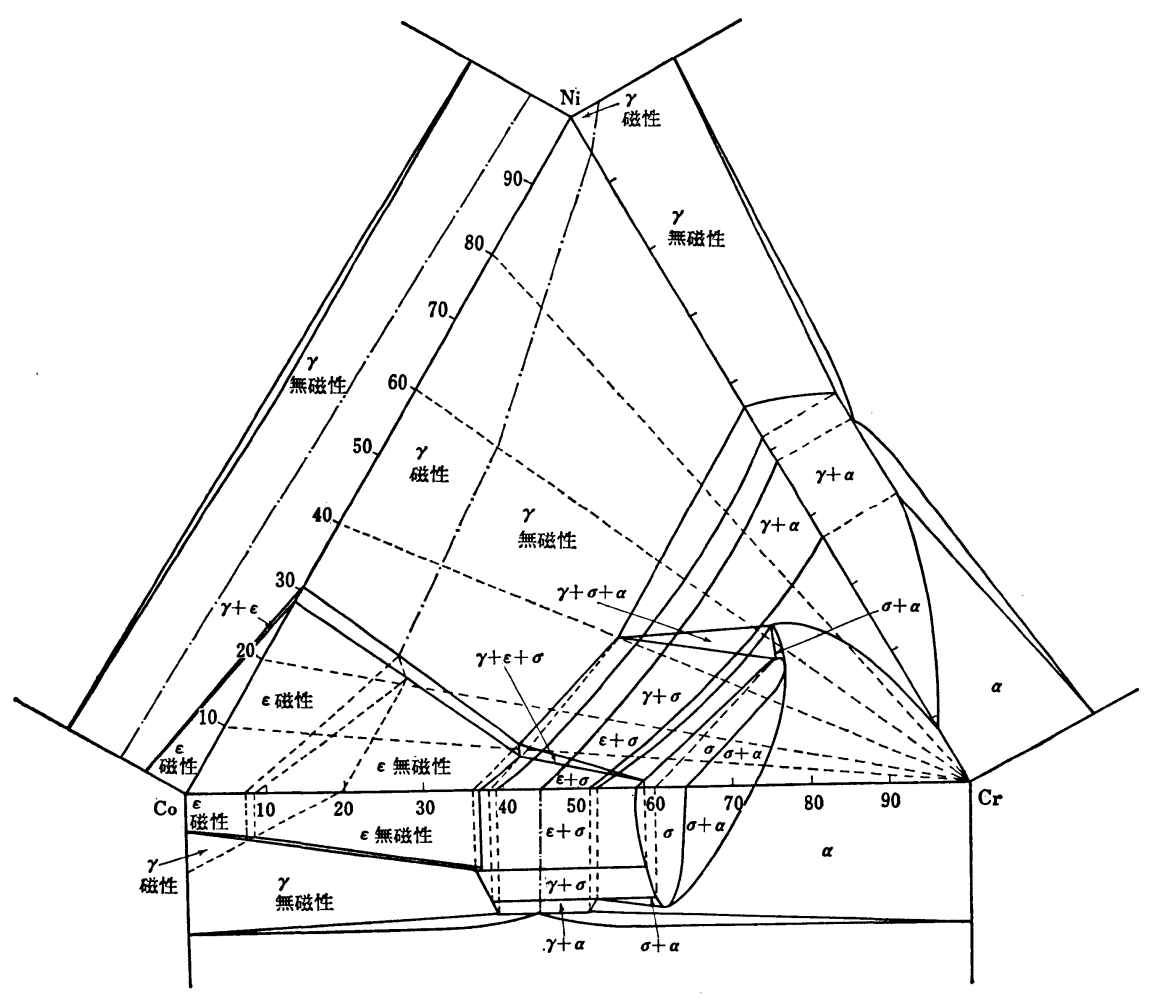

図 $9 \mathrm{Ni}-\mathrm{Co}-\mathrm{Cr}$ 三元平衡状態図

9.5\% のものであった。受入れのままのもの, 表面を研

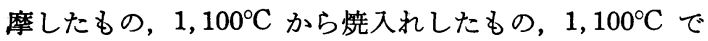
熱処理後 $650^{\circ} \mathrm{C}$ に 2 時間加熱したもの等について結果を まとめてみたところ, あるものは受入れのままの状態で 著しく腐食量の多いるのがあり，またあるものは受入れ 後研摩した試片と, これを $1,100^{\circ} \mathrm{C}$ から水焼入れ後研摩 したものの間で大差なき場合もあった。Krupp 社の板 の場合は受入れのままのものを $1,100^{\circ} \mathrm{C}$ から水焼入れす ると，その耐食性が著しく改良されるものもあった。

受入れのままの良否は出荷前の表面処理に関係がある のではないかと考えて, 研摩後種々の酸処理を試みてみ た。これらの結果から $650^{\circ} \mathrm{C}$ の熱処理による変化は前述 の種々の処理結果と同じ程度の影響を腐食試験結果に与 えるので $650^{\circ} \mathrm{C}$ の処理での劣化を調べる試験としては, 40\%硝酸試験ははなはだ不便なものであった。そのうえ 加工による劣化の状態などは更に識別が困難であった。 しかしすべての材料は加工によりエネルギーを吸収した 場合に，その腐食度が劣化することは当然のことである。 以上のごとく，40\% 硝酸によっては $650^{\circ} \mathrm{C}$ の鋭敏化 処理の影響も加工による影響も, これを識別するのがは なはだ困難であったので, 筆者はこの二つの問題を検定 する試験方法を模索した。その結果 $5 \%$ 硫酸がこの二つ の問題を識別するのにきわめて簡便で再現性のある方法
であることを確かめて，この方法を昭和 8 年以降売買の 仕様書として用いた。昭和 26 年以降は JIS 規格として この方法が採用されたことは筆者の誠に欣快とするとこ

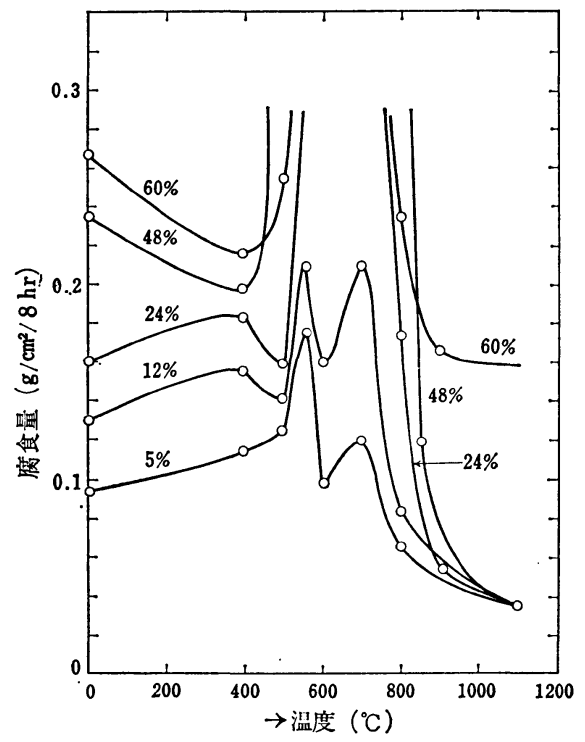

図 $10 \quad 18-8$ 鋼（治金工製）の $5 \%$ 沸騰硫酸による 腐食試験結果 （加工並びに加熱の影響） 


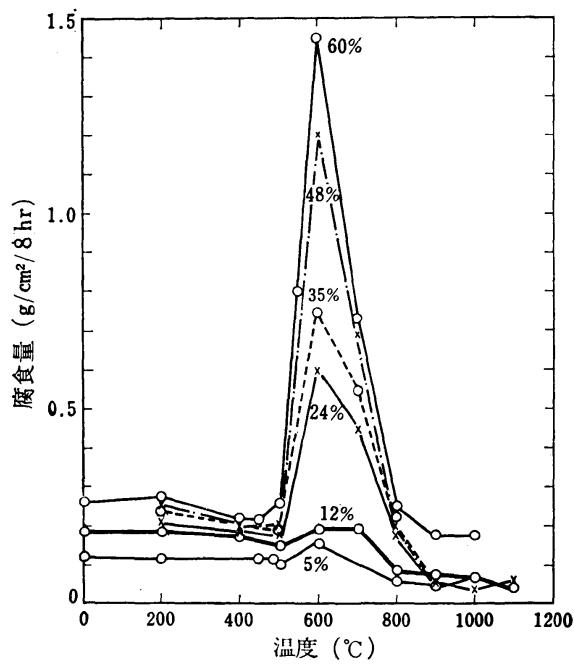

図 $11 \quad 18-8$ 鋼（Krupp 社製）の沸滕 $5 \%$ 硫酸による 腐食試験結果 （加工および加熱の影響）

ろである。この試験について筆者が昭和 7 年以降試みた 方法は，まず巾 $20 \mathrm{~mm}$, ゲージマーク $200 \mathrm{~mm}$ の引張 試片をつくり，これに $5,10 ， 20 ， 40,50 \%$ および破断 をするまでの伸びを与えてのち，これを $200 ， 400 ， 500$, $600,700,800,900^{\circ} \mathrm{C}$ 等の温度に 1 時間加熱してのち 水尭入れして前記 $5 \%$ 硫酸で腐食試験をした（図 10 , 11, および図 12)。当時の製品は前記の通り炭素量が最 低 0.08〜0.07\% であったので, 溶接その他の加工後, 必らず固溶化熱処理を施して使用されるものと想定して, 売買仕様書では熱処理を完了したものについて 5\% 硫酸 試験を行なったのである。

今日のように炭素量が $0.030 \%$ 以下のものが JIS 化さ れている時代では Huey 試験（65\% 硝酸試験）によっ て鋭敏化の状態に括ける粒界度食の試験が規定されてい るのであるから，5\% 硫酸試験に沶いても最大の加工を 与えたのち，鋭敏化処理したものを試験し，その值の一

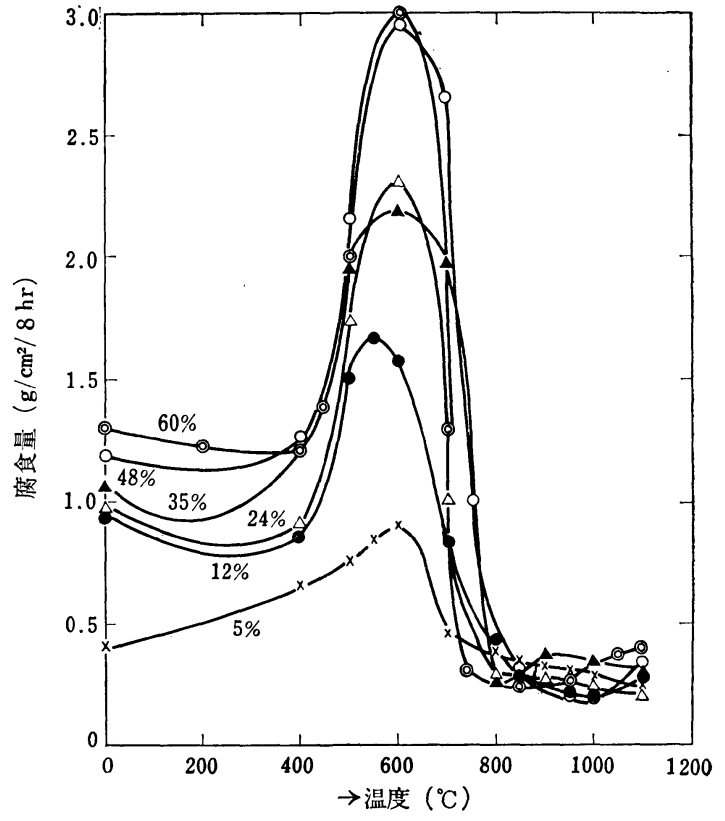

図 12 18-8 鋼 (Schöller-Bleckman 社製) の沸騰 $5 \%$ 硫酸による腐食試験結果 （加工および加熱の影響）

定のものを規格合格品とするように，その試験方法を改 訂すべき時期にきているように思われる。

終りに，創業に当り筆者が電熱線および 18-8 ステン レス鋼の製造技術を確立した日本金属工業株式会社（旧 日本電熱線株式会社）扣よび日本治金工業株式会社（旧 日本火工株式会社）は，ともに本邦 18-8 ステンレス鋼 の代表的製造会社として業界の王座にあるが，両者とも 創業苦難の時, 本研究の完遂に助力を文まれなかったこ とを感謝する。

またご指導ご鞭撻を賜わった本多，村上両博士ならび に直接助力をいただいた村瀬, 飛沢工学士に括礼を申し 述べたい。 